\title{
In Vitro Activity of Telavancin Against Clinically Important Gram-Positive Pathogens from 69 U.S. Medical Centers (2015): Potency Analysis by U.S. Census Divisions
}

\author{
Michael A. Pfaller, Helio S. Sader, ${ }^{1}$ Robert K. Flamm, ${ }^{1}$ Mariana Castanheira, \\ Jennifer I. Smart, ${ }^{2, \star}$ and Rodrigo E. Mendes ${ }^{1}$
}

A total of 8,072 gram-positive isolates collected from 69 medical centers among all 9 U.S. Census Divisions during the 2015 SENTRY Antimicrobial Surveillance Program were included. Telavancin had minimal inhibitory concentration (MIC) $)_{50}$ and $\mathrm{MIC}_{90}$ values of $0.03 / 0.06 \mu \mathrm{g} / \mathrm{mL}$, respectively, against methicillin-susceptible (MSSA) and methicillin-resistant Staphylococcus aureus (MRSA). Similar activity was also observed among coagulase-negative staphylococci $\left(\mathrm{MIC}_{50 / 90}, 0.03 / 0.06 \mu \mathrm{g} / \mathrm{ml} ; 100.0 \%\right.$ inhibited by $\leq 0.12 \mu \mathrm{g} / \mathrm{ml}$ ). Telavancin was active against vancomycin-susceptible Enterococcus faecalis $\left(\mathrm{MIC}_{50 / 90}, 0.12 / 0.12 \mu \mathrm{g} / \mathrm{ml}\right.$ ) and Enterococcus faecium $\left(\mathrm{MIC}_{50 / 90}, 0.03 / 0.06 \mu \mathrm{g} / \mathrm{ml}\right.$ ), but was less active against vancomycin-resistant E. faecium ( $\mathrm{MIC}_{90}$, $>2 \mu \mathrm{g} / \mathrm{ml}$ ) and E. faecalis ( $\mathrm{MIC}_{90},>2 \mu \mathrm{g} / \mathrm{ml}$ ). Streptococci showed modal MIC results of $0.008 \mu \mathrm{g} / \mathrm{ml}$ (Streptococcus pneumoniae) to $0.015 \mu \mathrm{g} / \mathrm{ml}$ ( $\beta$-hemolytic streptococci and viridans group streptococci). Potency variations for telavancin within Census Divisions were not observed. Telavancin remains potent in vitro against indicated pathogens recovered from U.S. medical centers (2015).

Keywords: telavancin, lipoglycopeptide, U.S. census, in vitro testing

\section{Introduction}

$\mathbf{T}$ ELAVANCIN IS A PARENTERAL, bactericidal, semisynthetic lipoglycopeptide agent that has been shown to be noninferior to vancomycin in phase 3 clinical trials of adult patients with complicated skin and skin structure infections (cSSSI) and in hospital-acquired bacterial pneumonia (HAP), including ventilator-associated pneumonia (VAP), due to susceptible gram-positive pathogens and Staphylococcus aureus, respectively. ${ }^{1-4}$ Telavancin has been approved for clinical use by the U.S. Food and Drug Administration (FDA) in the treatment (once daily) of cSSSI and HAP/VAP and demonstrated efficacy in treating patients with either cSSSI or HAP/VAP who had concurrent $S$. aureus bacteremia. ${ }^{4}$

Previous studies have demonstrated potent activity of telavancin against $S$. aureus, including methicillin-resistant (MRSA) strains, as well as heterogeneous vancomycinintermediate S. aureus (hVISA) and VISA isolates and vancomycin-susceptible Enterococcus faecalis. ${ }^{5,6}$ Not only does telavancin inhibit peptidoglycan synthesis but it also interacts with the bacterial cell membrane, causing depolarization and increased membrane permeability. ${ }^{7}$ This dual mechanism of action contributes to the bactericidal activity of telavancin and might also prevent the emergence of resistance when it is used clinically. In fact, only one report has been published of in vivo development of a nonsusceptible phenotype while on telavancin therapy (Swartz et al., 2013).

Recently, the broth microdilution (BMD) method recommended by the Clinical and Laboratory Standards Institute (CLSI) for testing telavancin was modified to conform to CLSI guidelines for water-insoluble agents. ${ }^{6,8,9}$ The revised method includes the use of dimethyl sulfoxide (DMSO) as both the solvent and diluent of stock solutions as well as the addition of polysorbate $80(\mathrm{P}-80 ; 0.002 \%)$ to the test medium. ${ }^{4,9}$ The net effects of these modifications are improved solubility and decreased binding on plastic trays of the active agent with resultant improved accuracy and

\footnotetext{
${ }^{1}$ JMI Laboratories, North Liberty, Iowa.

${ }^{2}$ Theravance Biopharma US, Inc., South San Francisco, California.

* Present affiliation: Basilea Pharmaceutica International AG, Basel, Switzerland.
}

(C) Michael A. Pfaller et al., 2017; Published by Mary Ann Liebert, Inc. This is an Open Access article distributed under the terms of the Creative Commons Attribution License, which permits unrestrieted use, distribution, and reproduction in any medium, provided the original work is properly cited. 
reproducibility of in vitro test results. ${ }^{9}$ As might be expected, these modifications result in lower minimal inhibitory concentration values for the target pathogens requiring. The FDA, CLSI, and European Committee on Antimicrobial Susceptibility Testing (EUCAST) to reestablish quality control (QC) MIC ranges and interpretive breakpoints. $4,6,8,9$ Mendes et al. ${ }^{6}$ subsequently used the revised BMD method to assess the baseline activity of telavancin against grampositive target species obtained from a limited number ( $N=28$ sites) of U.S. hospitals in 2011-2012. The objective of the present study was to expand on the study of Mendes et al. ${ }^{6}$ by including isolates from a total of 69 institutions (35 states) across all 9 U.S. Census Divisions for the year 2015. Testing was performed using the revised CLSI method with the new QC MIC ranges and interpretive criteria. ${ }^{8}$

\section{Materials and Methods}

\section{Organism collection}

During 2015, a total of 8,072 gram-positive bacterial pathogens were collected from 69 medical centers in 35 states across all 9 U.S. Census Bureau Divisions. Each participating laboratory followed a protocol to submit consecutive isolates (1 per patient episode) determined to be pathogens to the monitoring laboratory (JMI Laboratories, North Liberty, IA). These isolates were deemed responsible for SSSI (42.8\%), pneumonia in hospitalized patients $(22.5 \%)$, bloodstream infections $(18.5 \%)$, urinary tract infections $(5.3 \%)$, community-acquired pneumonia $(4.8 \%)$, intra-abdominal infections $(2.8 \%)$, and other unknown or less prevalent infections (3.1\%). There were 3 to 12 medical centers in each U.S. Census Bureau Division, and a total of 631 to 1,526 strains were contributed per division. Among the 8,072 isolates tested, there were 5,123 of $S$. aureus (2,822 methicillin-susceptible and 2,301 MRSAs), 328 of coagulase-negative staphylococci (CoNS), 815 of Enterococcus spp., 447 of Streptococcus pneumoniae, 1,083 of $\beta$-hemolytic streptococci (BHS), and 276 of viridans group streptococci (VGS). See footnote of Table 1 for complete list of isolates included in the study. The isolates were identified locally and forwarded to the central monitoring laboratory for confirmation of species identification, using matrix-assisted laser desorption-ionization time-of-flight mass spectrometry [MALDI-TOF-MS] and/or manual methods), and reference antimicrobial susceptibility testing.

\section{Susceptibility testing}

Isolates were tested for susceptibility to telavancin and comparator agents by BMD following the CLSI-approved standard. ${ }^{10}$ Testing was performed using panels manufactured by JMI Laboratories (North Liberty, IA). These panels provide telavancin MIC results equivalent to the revised FDAapproved BMD method. ${ }^{4,6,8,9}$ Bacterial inoculum density was monitored by colony counts to ensure an adequate number of cells for each testing event. Validation of MIC values was performed by concurrent testing of CLSI-recommended QC reference strains: $S$. aureus ATCC 29213, E. faecalis ATCC 29212, and S. pneumoniae ATCC 49619. ${ }^{4,8}$ All QC results were within published acceptable ranges. The MIC interpretations for telavancin and comparator agents, when tested against clinical isolates, were based on the most updated breakpoint criteria from CLSI (2016). The EUCAST breakpoint for teicoplanin $(\leq 2 />2 \mu \mathrm{g} / \mathrm{ml}$ for susceptible and resistant, respectively) was applied against BHS and VGS. ${ }^{11}$

\section{Results}

\section{Activity of telavancin and comparators} against $\mathrm{S}$. aureus

Overall, $2,822(55.1 \%)$ of $S$. aureus isolates were MSSAs and 2,301 (44.9\%) were MRSAs. At least $50 \%$ of $S$. aureus isolates from U.S. Census Divisions 2 (Mid-Atlantic, 50.0\%), 6 (East South Central, 56.6\%), and 7 (West South Central, $52.4 \%$ ) were MRSAs, whereas $<40 \%$ of isolates from divisions 1 (New England, 35.3\%) and 4 (West North Central, $33.6 \%$ ) exhibited that phenotype (Table 2).

Telavancin $\mathrm{MIC}_{50 / 90}$ values $(0.03 / 0.06 \mu \mathrm{g} / \mathrm{ml})$ were identical for both MSSA and MRSA and $100.0 \%$ of isolates of $S$. aureus were inhibited at the approved breakpoint for susceptibility (i.e., $\leq 0.12 \mu \mathrm{g} / \mathrm{ml}$ ) (Tables 1 and 3). The activity of telavancin ( $\mathrm{MIC}_{50}$ values) against $S$. aureus was similar across all nine U.S. Census Divisions with $\mathrm{MIC}_{90}$ values of $0.03-0.06 \mu \mathrm{g} / \mathrm{ml}$ (Table 2). Using CLSI breakpoints, $100.0 \%$ of isolates tested were also susceptible to daptomycin, teicoplanin, and vancomycin (Table 3). Susceptibility rates (CLSI interpretations) to erythromycin and levofloxacin were $40.8 \%$ and $62.0 \%$, respectively. Susceptibility percentages were much higher to ceftaroline (98.4\%), gentamicin (97.2\%), linezolid (>99.9\%), tetracycline $(95.2 \%)$, and trimethoprimsulfamethoxazole (98.4\%). These agents showed comparable activity against both MSSA and MRSA (Table 3).

\section{Activity of telavancin against CoNS}

All CoNS were inhibited by $\leq 0.12 \mu \mathrm{g} / \mathrm{ml}$ of telavancin (Table 1). The rate of methicillin-resistant CoNS (MR-CoNS) was $55.8 \%$ overall, ranging from $24.0 \%$ in the Mountain Division to $71.4 \%$ in the West South Central Division (Table 2). The activity of telavancin did not vary across the nine U.S. Census Divisions ( $\mathrm{MIC}_{90}, 0.06-0.12 \mu \mathrm{g} / \mathrm{ml}$ ) (Table 2). All CoNS were susceptible to daptomycin and vancomycin (Table 3). Susceptibility percentages to linezolid and teicoplanin were also high against methicillin-susceptible CoNS (MS-CoNS) (both 100.0\%) and MR-CoNS (both $98.4 \%$ ). Relative to telavancin $\mathrm{MIC}_{90}$ values, ceftaroline and daptomycin were 4- to 8-fold less potent, linezolid was 16-fold less potent, and vancomycin was 16- to 32-fold less potent against both MS- and MR-CoNS (Table 3). Other agents tested against CoNS did not show useful (susceptibility $>90 \%$ ) in vitro activity, with susceptibility of $\leq 85.4 \%$ (range $41.5-85.4 \%$ ) and MIC $_{90}$ values of $>2 \mu \mathrm{g} / \mathrm{ml}$ (Table 3).

Susceptibility to clindamycin, erythromycin, gentamicin, levofloxacin, tetracycline, and trimethoprim-sulfamethoxazole was lower for MR-CoNS than for MS-CoNS (Table 3). For example, susceptibility to erythromycin was $24.6 \%$ for MRCoNS and $62.8 \%$ for MS-CoNS (Table 3). Susceptibility to levofloxacin was $35.5 \%$ for MR-CoNS and $86.2 \%$ for MSCoNS (Table 3).

\section{Activity of telavancin against $\mathrm{E}$. faecalis}

A total of 815 enterococci were tested, of which $53.7 \%$ were E. faecalis (Table 1). These isolates were very susceptible to 


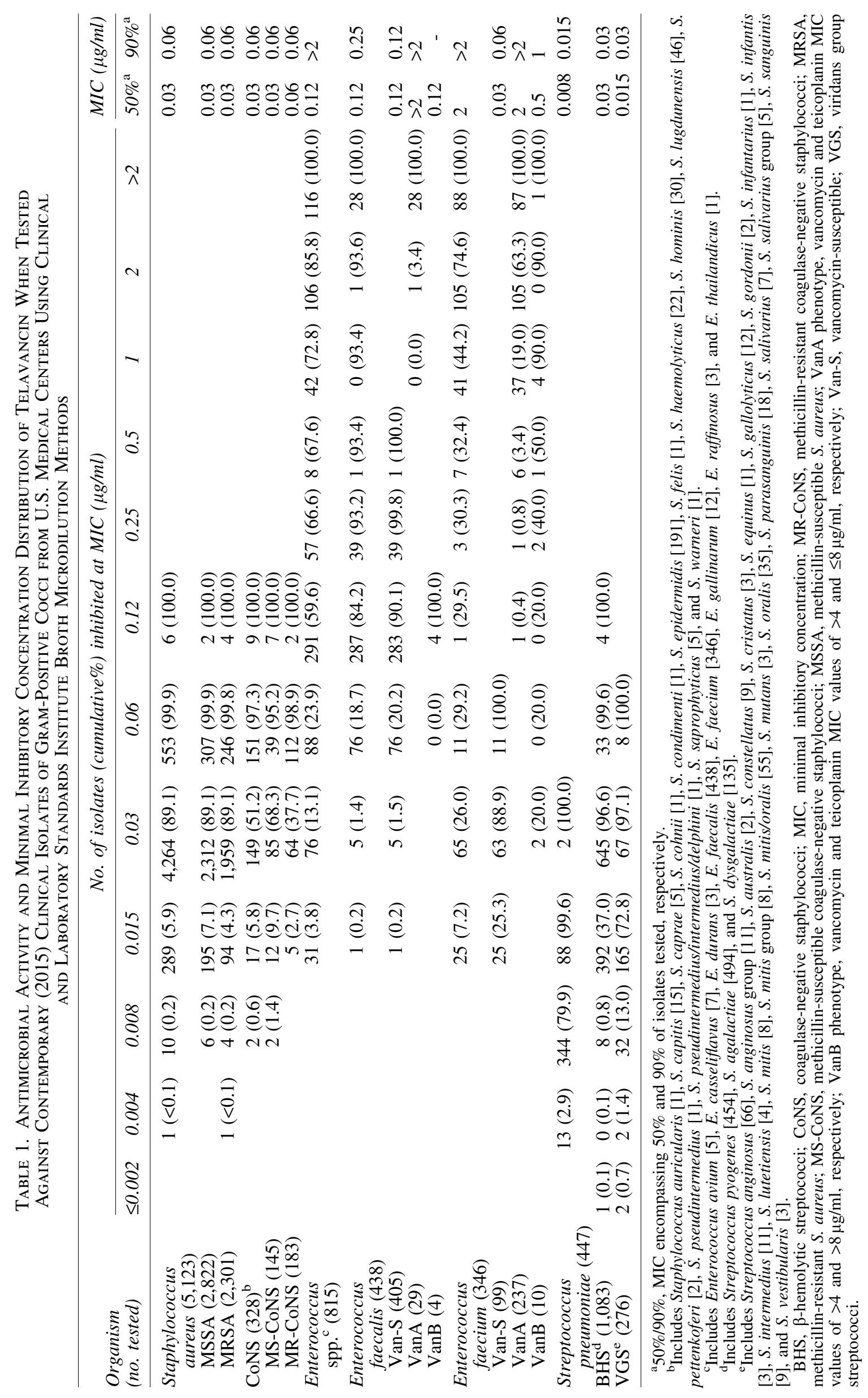


Table 2. Antimicrobial Activity of Telavancin Tested Against Gram-Positive Clinical Isolates From Each of the Nine U.S. Census Bureau Divisions

\begin{tabular}{|c|c|c|c|c|c|c|}
\hline \multirow[b]{2}{*}{ Division (no. of sites) } & \multirow[b]{2}{*}{ Organism } & \multirow[b]{2}{*}{ No. tested } & \multicolumn{3}{|c|}{$M I C(\mu g / m l)$} & \multirow[b]{2}{*}{$\%$ Susceptible } \\
\hline & & & Range & $50 \%$ & $90 \%$ & \\
\hline \multirow[t]{13}{*}{ 1. New England (3) } & S. aureus & 430 & 0.008 to 0.006 & 0.03 & 0.06 & 100.0 \\
\hline & MSSA & 278 & 0.008 to 0.06 & 0.03 & 0.06 & 100.0 \\
\hline & MRSA & 152 & 0.015 to 0.06 & 0.03 & 0.06 & 100.0 \\
\hline & CoNS & 18 & 0.015 to 0.06 & 0.03 & 0.06 & \\
\hline & MS-CoNS & 11 & 0.015 to 0.06 & 0.03 & 0.06 & \\
\hline & MR-CoNS & 7 & 0.03 to 0.06 & 0.06 & - & \\
\hline & E. faecalis & 36 & 0.06 to $>2$ & 0.12 & 0.25 & \\
\hline & Van-S & 35 & 0.06 to 0.25 & 0.12 & 0.25 & 100.0 \\
\hline & E. faecium & 18 & 0.015 to $>2$ & 2 & $>2$ & \\
\hline & Van-S & 7 & 0.015 to 0.06 & 0.03 & - & \\
\hline & S. pneumoniae & 36 & 0.008 to 0.03 & 0.008 & 0.015 & \\
\hline & BHS & 63 & 0.008 to 0.03 & 0.03 & 0.03 & 100.0 \\
\hline & VGS & 19 & 0.008 to 0.03 & 0.015 & 0.03 & 100.0 \\
\hline \multirow[t]{13}{*}{ 2. Mid-Atlantic (7) } & S. aureus & 508 & 0.008 to 0.06 & 0.03 & 0.06 & 100.0 \\
\hline & MSSA & 254 & 0.015 to 0.06 & 0.03 & 0.06 & 100.0 \\
\hline & MRSA & 254 & 0.008 to 0.06 & 0.03 & 0.06 & 100.0 \\
\hline & CoNS & 29 & 0.03 to 0.12 & 0.06 & 0.12 & \\
\hline & MS-CoNS & 13 & 0.03 to 0.12 & 0.06 & 0.12 & \\
\hline & MR-CoNS & 16 & 0.03 to 0.12 & 0.06 & 0.06 & \\
\hline & E. faecalis & 50 & 0.06 to $>2$ & 0.12 & 0.25 & \\
\hline & Van-S & 44 & 0.06 to 0.25 & 0.12 & 0.25 & 100.0 \\
\hline & E. faecium & 48 & 0.015 to $>2$ & 2 & $>2$ & \\
\hline & Van-S & 8 & 0.015 to 0.06 & 0.03 & 0.06 & \\
\hline & S. pneumoniae & 42 & 0.004 to 0.015 & 0.008 & 0.015 & \\
\hline & BHS & 113 & 0.008 to 0.12 & 0.03 & 0.03 & 100.0 \\
\hline & VGS & 30 & 0.008 to 0.03 & 0.015 & 0.03 & 100.0 \\
\hline \multirow[t]{13}{*}{ 3. East North Central (12) } & S. aureus & 922 & 0.008 to 0.06 & 0.03 & 0.03 & 100.0 \\
\hline & MSSA & 516 & 0.008 to 0.06 & 0.03 & 0.06 & 100.0 \\
\hline & MRSA & 406 & 0.008 to 0.06 & 0.03 & 0.03 & 100.0 \\
\hline & CoNS & 64 & 0.008 to 0.06 & 0.03 & 0.06 & \\
\hline & MS-CoNS & 30 & 0.008 to 0.06 & 0.03 & 0.06 & \\
\hline & MR-CoNS & 34 & 0.03 to 0.06 & 0.06 & 0.06 & \\
\hline & E. faecalis & 81 & 0.015 to $>2$ & 0.12 & 0.25 & \\
\hline & Van-S & 77 & 0.015 to 0.25 & 0.12 & 0.12 & 100.0 \\
\hline & E. faecium & 63 & 0.015 to $>2$ & 2 & $>2$ & \\
\hline & Van-S & 21 & 0.015 to 0.06 & 0.03 & 0.06 & \\
\hline & S. pneumoniae & 100 & 0.004 to 0.015 & 0.008 & 0.015 & \\
\hline & BHS & 234 & 0.002 to 0.12 & 0.03 & 0.03 & 100.0 \\
\hline & VGS & 56 & 0.008 to 0.06 & 0.015 & 0.03 & 100.0 \\
\hline \multirow[t]{13}{*}{ 4. West North Central (7) } & S. aureus & 541 & 0.008 to 0.12 & 0.03 & 0.06 & 100.0 \\
\hline & MSSA & 359 & 0.008 to 0.06 & 0.03 & 0.06 & 100.0 \\
\hline & MRSA & 182 & 0.008 to 0.12 & 0.03 & 0.03 & 100.0 \\
\hline & CoNS & 29 & 0.015 to 0.06 & 0.03 & 0.06 & \\
\hline & MS-CoNS & 11 & 0.015 to 0.06 & 0.03 & 0.06 & \\
\hline & MR-CoNS & 18 & 0.015 to 0.06 & 0.06 & 0.06 & \\
\hline & E. faecalis & 44 & 0.06 to $>2$ & 0.12 & 0.25 & \\
\hline & Van-S & 40 & 0.06 to 0.25 & 0.12 & 0.25 & 100.0 \\
\hline & E. faecium & 22 & 0.015 to $>2$ & 0.03 & $>2$ & \\
\hline & Van-S & 11 & 0.015 to 0.03 & 0.03 & 0.03 & \\
\hline & S. pneumoniae & 50 & 0.004 to 0.015 & 0.008 & 0.015 & \\
\hline & BHS & 147 & 0.015 to 0.06 & 0.03 & 0.03 & 100.0 \\
\hline & VGS & 38 & 0.002 to 0.06 & 0.015 & 0.03 & 100.0 \\
\hline \multirow[t]{7}{*}{ 5. South Atlantic (9) } & S. aureus & 842 & 0.004 to 0.12 & 0.03 & 0.06 & 100.0 \\
\hline & MSSA & 428 & 0.008 to 0.12 & 0.03 & 0.06 & 100.0 \\
\hline & MRSA & 414 & 0.004 to 0.12 & 0.03 & 0.06 & 100.0 \\
\hline & CoNS & 56 & 0.015 to 0.06 & 0.03 & 0.06 & \\
\hline & MS-CoNS & 21 & 0.015 to 0.06 & 0.03 & 0.06 & \\
\hline & MR-CoNS & 35 & 0.03 to 0.06 & 0.06 & 0.06 & \\
\hline & E. faecalis & 53 & 0.06 to $>2$ & 0.12 & 0.25 & \\
\hline
\end{tabular}


TABle 2. (CONTINUED)

\begin{tabular}{|c|c|c|c|c|c|c|}
\hline \multirow[b]{2}{*}{ Division (no. of sites) } & \multirow[b]{2}{*}{ Organism } & \multirow[b]{2}{*}{ No. tested } & \multicolumn{3}{|c|}{$M I C(\mu g / m l)$} & \multirow[b]{2}{*}{ \% Susceptible } \\
\hline & & & Range & $50 \%$ & $90 \%$ & \\
\hline & Van-S & 46 & 0.06 to 0.25 & 0.12 & 0.12 & 100.0 \\
\hline & E. faecium & 43 & 0.015 to $>2$ & 2 & $>2$ & \\
\hline & Van-S & 9 & 0.015 to 0.03 & 0.03 & - & \\
\hline & S. pneumoniae & 47 & 0.004 to 0.015 & 0.008 & 0.015 & \\
\hline & BHS & 126 & 0.015 to 0.12 & 0.03 & 0.03 & 100.0 \\
\hline & VGS & 34 & 0.008 to 0.06 & 0.015 & 0.03 & 100.0 \\
\hline \multirow[t]{13}{*}{ 6. East South Central (6) } & S. aureus & 426 & 0.05 to 0.06 & 0.03 & 0.06 & 100.0 \\
\hline & MSSA & 185 & 0.015 to 0.06 & 0.03 & 0.06 & 100.0 \\
\hline & MRSA & 241 & 0.0115 to 0.06 & 0.03 & 0.06 & 100.0 \\
\hline & CoNS & 23 & 0.015 to 0.06 & 0.03 & 0.06 & \\
\hline & MS-CoNS & 8 & 0.015 to 0.06 & 0.03 & - & \\
\hline & MR-CoNS & 15 & 0.015 to 0.06 & 0.03 & 0.06 & \\
\hline & E. faecalis & 50 & 0.06 to $>2$ & 0.12 & 0.25 & \\
\hline & Van-S & 48 & 0.06 to 0.25 & 0.12 & 0.25 & 100.0 \\
\hline & E. faecium & 29 & 0.015 to $>2$ & 2 & $>2$ & \\
\hline & Van-S & 3 & 0.015 to 0.03 & 0.03 & - & \\
\hline & S. pneumoniae & 31 & 0.004 to 0.015 & 0.008 & 0.015 & \\
\hline & BHS & 70 & 0.015 to 0.06 & 0.03 & 0.03 & 100.0 \\
\hline & VGS & 20 & 0.004 to 0.03 & 0.015 & 0.015 & 100.0 \\
\hline \multirow[t]{13}{*}{ 7. West South Central (7) } & S. aureus & 361 & 0.015 to 0.12 & 0.03 & 0.03 & 100.0 \\
\hline & MSSA & 172 & 0.015 to 0.12 & 0.03 & 0.03 & 100.0 \\
\hline & MRSA & 189 & 0.015 to 0.06 & 0.03 & 0.03 & 100.0 \\
\hline & CoNS & 35 & 0.015 to 0.12 & 0.06 & 0.06 & \\
\hline & MS-CoNS & 10 & 0.03 to 0.12 & 0.06 & 0.12 & \\
\hline & MR-CoNS & 25 & 0.015 to 0.12 & 0.06 & 0.06 & \\
\hline & E. faecalis & 38 & 0.03 to $>2$ & 0.12 & 0.5 & \\
\hline & Van-S & 35 & 0.03 to 0.5 & 0.12 & 0.12 & 97.1 \\
\hline & E. faecium & 57 & 0.015 to $>2$ & 2 & $>2$ & \\
\hline & Van-S & 18 & 0.015 to 0.06 & 0.03 & 0.06 & \\
\hline & S. pneumoniae & 43 & 0.004 to 0.015 & 0.008 & 0.015 & \\
\hline & BHS & 78 & 0.008 to 0.06 & 0.03 & 0.03 & 100.0 \\
\hline & VGS & 14 & 0.008 to 0.06 & 0.015 & 0.03 & 100.0 \\
\hline \multirow[t]{13}{*}{ 8. Mountain (6) } & S. aureus & 446 & 0.015 to 0.06 & 0.03 & 0.03 & 100.0 \\
\hline & MSSA & 256 & 0.015 to 0.06 & 0.03 & 0.03 & 100.0 \\
\hline & MRSA & 190 & 0.015 to 0.06 & 0.03 & 0.06 & 100.0 \\
\hline & CoNS & 25 & 0.008 to 0.12 & 0.03 & 0.06 & \\
\hline & MS-CoNS & 19 & 0.008 to 0.12 & 0.03 & 0.06 & \\
\hline & MR-CoNS & 6 & 0.03 to 0.06 & 0.06 & - & \\
\hline & E. faecalis & 25 & 0.06 to $>2$ & 0.12 & 0.12 & \\
\hline & Van-S & 24 & 0.06 to 0.12 & 0.12 & 0.12 & 100.0 \\
\hline & E. faecium & 34 & 0.015 to 2 & 2 & $>2$ & \\
\hline & Van-S & 22 & 1 to $>2$ & 2 & $>2$ & \\
\hline & S. pneumoniae & 20 & 0.004 to 0.03 & 0.008 & 0.015 & \\
\hline & BHS & 11 & 0.008 to 0.06 & 0.03 & 0.03 & 100.0 \\
\hline & VGS & 28 & 0.008 to 0.03 & 0.015 & 0.03 & 100.0 \\
\hline \multirow[t]{13}{*}{ 9. Pacific (11) } & S. aureus & 647 & 0.008 to 0.12 & 0.03 & 0.06 & 100.0 \\
\hline & MSSA & 374 & 0.008 to 0.06 & 0.03 & 0.06 & 100.0 \\
\hline & MRSA & 273 & 0.015 to 0.12 & 0.03 & 0.06 & 100.0 \\
\hline & CoNS & 49 & 0.015 to 0.12 & 0.06 & 0.06 & \\
\hline & MS-CoNS & 22 & 0.015 to 0.12 & 0.03 & 0.06 & \\
\hline & MR-CoNS & 27 & 0.015 to 0.06 & 0.06 & 0.06 & \\
\hline & E. faecalis & 61 & 0.03 to $>2$ & 0.12 & 0.25 & \\
\hline & Van-S & 56 & 0.03 to 0.25 & 0.12 & 0.12 & 100.0 \\
\hline & E. faecium & 32 & 0.015 to $>2$ & 1 & $>2$ & \\
\hline & Van-S & 12 & 0.015 to 0.06 & 0.03 & 0.06 & \\
\hline & S. pneumoniae & 68 & 0.004 to 0.015 & 0.008 & 0.015 & \\
\hline & BHS & 141 & 0.008 to 0.06 & 0.03 & 0.03 & 100.0 \\
\hline & VGS & 37 & 0.008 to 0.06 & 0.015 & 0.03 & 100.0 \\
\hline
\end{tabular}

${ }^{\mathrm{a}}$ Criteria as published by CLSI (2016) against indicated pathogens. Breakpoint for Streptococcus agalactiae, Streptococcus pyogenes, Streptococcus dysgalactiae, and Streptococcus anginosus group S. anginosus group applied for BHS and VGS.

CLSI, Clinical and Laboratory Standards Institute. 
Table 3. Antimicrobial Activity of Telavancin and Comparator Agents Tested Against Gram-Positive Clinical Isolates from the United States Using the Clinical and Laboratory Standards Institute Broth Microdilution Testing Method

\begin{tabular}{|c|c|c|c|c|c|c|c|}
\hline \multirow[b]{2}{*}{ Organism (no. tested) } & \multirow[b]{2}{*}{ Agent } & \multicolumn{3}{|c|}{$M I C(\mu g / m l)$} & \multicolumn{3}{|c|}{$\%$ By category ${ }^{\mathrm{a}}$} \\
\hline & & Range & $50 \%$ & $90 \%$ & $S$ & $I$ & $R$ \\
\hline \multirow[t]{13}{*}{ S. aureus $(5,123)$} & Telavancin & $\leq 0.004$ to 0.12 & 0.03 & 0.06 & 100.0 & & \\
\hline & Ceftaroline & $\leq 0.06$ to 2 & 0.25 & 1 & 98.4 & 1.6 & 0.0 \\
\hline & Clindamycin & $\leq 0.25$ to $>2$ & $\leq 0.25$ & $>2$ & 84.4 & 0.3 & 15.3 \\
\hline & Daptomycin & $\leq 0.12$ to 1 & 0.25 & 0.5 & 100.0 & & \\
\hline & Erythromycin & $\leq 0.06$ to $>8$ & $>8$ & $>8$ & 40.8 & 5.9 & 53.3 \\
\hline & Gentamicin & $\leq 1$ to $>8$ & $\leq 1$ & $\leq 1$ & 97.2 & 0.2 & 2.7 \\
\hline & Levofloxacin & $\leq 0.03$ to $>4$ & 0.25 & $>4$ & 62.0 & 1.0 & 36.9 \\
\hline & Linezolid & $\leq 0.12$ to 8 & 1 & 1 & $>99.9$ & & $<0.1$ \\
\hline & Oxacillin & $\leq 0.25$ to $>2$ & 1 & $>2$ & 55.1 & & 44.9 \\
\hline & Teicoplanin & $\leq 0.5$ to 8 & $\leq 0.5$ & $\leq 0.5$ & 100.0 & 0.0 & 0.0 \\
\hline & Tetracycline & $\leq 0.5$ to $>8$ & $\leq 0.5$ & $\leq 0.5$ & 95.2 & 0.9 & 3.8 \\
\hline & TMX-SMX & $\leq 0.5$ to $>4$ & $\leq 0.5$ & $\leq 0.5$ & 98.4 & & 1.6 \\
\hline & Vancomycin & $\leq 0.12$ to 2 & 0.5 & 1 & 100.0 & 0.0 & 0.0 \\
\hline \multirow[t]{13}{*}{ MSSA $(2,822)$} & Telavancin & 0.008 to 0.12 & 0.03 & 0.06 & 100.0 & & \\
\hline & Ceftaroline & $\leq 0.06$ to 0.5 & 0.25 & 0.25 & 100.0 & 0.0 & 0.0 \\
\hline & Clindamycin & $\leq 0.25$ to $>2$ & $\leq 0.25$ & $\leq 0.25$ & 94.8 & 0.2 & 5.0 \\
\hline & Daptomycin & $\leq 0.12$ to 1 & 0.25 & 0.5 & 100.0 & & \\
\hline & Erythromycin & $\leq 0.06$ to $>8$ & 0.25 & $>8$ & 64.6 & 7.4 & 27.9 \\
\hline & Gentamicin & $\leq 1$ to $>8$ & $\leq 1$ & $\leq 1$ & 98.5 & 0.2 & 1.3 \\
\hline & Levofloxacin & $\leq 0.03$ to $>4$ & 0.12 & 4 & 88.3 & 0.4 & 11.3 \\
\hline & Linezolid & $\leq 0.12$ to 2 & 1 & 1 & 100.0 & & 0.0 \\
\hline & Oxacillin & $\leq 0.25$ to 2 & 0.5 & 1 & 100.0 & & 0.0 \\
\hline & Teicoplanin & $\leq 0.5$ to 8 & $\leq 0.5$ & $\leq 0.5$ & 100.0 & 0.0 & 0.0 \\
\hline & Tetracycline & $\leq 0.5$ to $>4$ & $\leq 0.5$ & $\leq 0.5$ & 96.5 & 0.8 & 2.8 \\
\hline & TMX-SMX & $\leq 0.5$ to $>4$ & $\leq 0.5$ & $\leq 0.5$ & 99.6 & & 0.4 \\
\hline & Vancomycin & $\leq 0.12$ to 2 & 0.5 & 1 & 100.0 & 0.0 & 0.0 \\
\hline \multirow[t]{13}{*}{ MRSA $(2,301)$} & Telavancin & $\leq 0.004$ to 0.12 & 0.03 & 0.06 & 100.0 & & \\
\hline & Ceftaroline & 0.25 to 2 & 0.5 & 1 & 96.4 & 3.6 & 0.0 \\
\hline & Clindamycin & $\leq 0.25$ to $>2$ & $\leq 0.25$ & $>2$ & 71.7 & 0.4 & 27.9 \\
\hline & Daptomycin & $\leq 0.12$ to 1 & 0.25 & 0.5 & 100.0 & & \\
\hline & Erythromycin & $\leq 0.06$ to $>8$ & $>8$ & $>8$ & 11.6 & 4.0 & 84.4 \\
\hline & Gentamicin & $\leq 1$ to $>8$ & $\leq 1$ & $\leq 1$ & 95.5 & 0.1 & 4.4 \\
\hline & Levofloxacin & 0.12 to $>4$ & 4 & $>4$ & 29.9 & 1.8 & 68.3 \\
\hline & Linezolid & $\leq 0.12$ to 8 & 1 & 1 & $>99.9$ & & $<0.1$ \\
\hline & Oxacillin & $>2$ to $>2$ & $>2$ & $>2$ & 0.0 & & 100.0 \\
\hline & Teicoplanin & $\leq 0.5$ to $>8$ & $\leq 0.5$ & $\leq 0.5$ & 100.0 & 0.0 & 0.0 \\
\hline & Tetracycline & $\leq 0.5$ to $>8$ & $\leq 0.5$ & 1 & 93.7 & 1.1 & 5.2 \\
\hline & TMX-SMX & $\leq 0.5$ to $>4$ & $\leq 0.5$ & $\leq 0.5$ & 96.9 & & 3.1 \\
\hline & Vancomycin & $\leq 0.12$ to 2 & 0.5 & 1 & 100.0 & 0.0 & 0.0 \\
\hline \multirow[t]{12}{*}{ CoNS (328) } & Telavancin & 0.008 to 0.12 & 0.03 & 0.06 & & & \\
\hline & Ceftaroline & $\leq 0.06$ to 4 & 0.25 & 0.5 & & & \\
\hline & Clindamycin & $\leq 0.25$ to $>2$ & $\leq 0.25$ & $>2$ & 72.6 & 3.0 & 24.4 \\
\hline & Daptomycin & $\leq 0.12$ to 1 & 0.5 & 0.5 & 100.0 & & \\
\hline & Erythromycin & $\leq 0.06$ to $>8$ & $>8$ & $>8$ & 41.5 & 1.8 & 56.7 \\
\hline & Gentamicin & $\leq 1$ to $>8$ & $\leq 1$ & $>8$ & 79.0 & 2.4 & 18.6 \\
\hline & Levofloxacin & $\leq 0.03$ to $>4$ & 0.25 & $>4$ & 57.9 & 1.5 & 40.5 \\
\hline & Linezolid & $\leq 0.12$ to $>8$ & 0.5 & 1 & 99.1 & & 0.9 \\
\hline & Oxacillin & $\leq 0.25$ to $>2$ & 2 & $>2$ & 44.2 & & 55.8 \\
\hline & Teicoplanin & $\leq 0.5$ to 16 & 2 & 4 & 99.1 & 0.9 & 0.0 \\
\hline & Tetracycline & $\leq 0.5$ to $>8$ & $\leq 0.5$ & $>8$ & 85.4 & 1.5 & 13.1 \\
\hline & Vancomycin & $\leq 0.12$ to 2 & 1 & 2 & 100.0 & 0.0 & 0.0 \\
\hline \multirow[t]{13}{*}{ MS-CoNS (145) } & Telavancin & 0.008 to 0.12 & 0.03 & 0.06 & & & \\
\hline & Ceftaroline & $\leq 0.06$ to 0.25 & $\leq 0.06$ & 0.25 & & & \\
\hline & Clindamycin & $\leq 0.25$ to $>2$ & $\leq 0.25$ & 0.5 & 90.3 & 1.4 & 8.3 \\
\hline & Daptomycin & $\leq 0.12$ to 1 & 0.25 & 0.5 & 100.0 & & \\
\hline & Erythromycin & $\leq 0.06$ to $>8$ & 0.12 & $>8$ & 62.8 & 2.1 & 35.2 \\
\hline & Gentamicin & $\leq 1$ to $>8$ & $\leq 1$ & $\leq 1$ & 97.9 & 0.0 & 2.1 \\
\hline & Levofloxacin & $\leq 0.03$ to $>4$ & 0.25 & $>4$ & 86.2 & 0.0 & 13.8 \\
\hline & Linezolid & $\leq 0.12$ to 2 & 0.5 & 1 & 100.0 & & 0.0 \\
\hline & Oxacillin & $\leq 0.25$ to 1 & $\leq 0.25$ & 0.5 & 100.0 & & 0.0 \\
\hline & Teicoplanin & $\leq 0.5$ to 8 & $\leq 0.5$ & 4 & 100.0 & 0.0 & 0.0 \\
\hline & Tetracycline & $\leq 0.5$ to $>8$ & $\leq 0.5$ & 2 & 90.3 & 2.8 & 6.9 \\
\hline & TMX-SMX & $\leq 0.5$ to $>4$ & $\leq 0.5$ & 1 & 92.4 & & 7.6 \\
\hline & Vancomycin & $\leq 0.12$ to 2 & 0.5 & 2 & 100.0 & 0.0 & 0.0 \\
\hline
\end{tabular}


TABle 3. (CONTINUED)

\begin{tabular}{|c|c|c|c|c|c|c|c|}
\hline \multirow[b]{2}{*}{ Organism (no. tested) } & \multirow[b]{2}{*}{ Agent } & \multicolumn{3}{|c|}{$M I C(\mu g / m l)$} & \multicolumn{3}{|c|}{$\%$ By category ${ }^{\mathrm{a}}$} \\
\hline & & Range & $50 \%$ & $90 \%$ & $S$ & $I$ & $R$ \\
\hline \multirow{13}{*}{ MR-CoNS (183) } & Telavancin & 0.015 to 0.12 & 0.06 & 0.06 & & & \\
\hline & Ceftaroline & $\leq 0.06$ to 4 & 0.25 & 0.5 & & & \\
\hline & Clindamycin & $\leq 0.25$ to $>2$ & $\leq 0.25$ & $>2$ & 58.5 & 4.4 & 37.2 \\
\hline & Daptomycin & $\leq 0.12$ to 1 & 0.5 & 0.5 & 100.0 & & \\
\hline & Erythromycin & $\leq 0.06$ to $>8$ & $>8$ & $>8$ & 24.6 & 1.6 & 73.8 \\
\hline & Gentamicin & $\leq 1$ to $>8$ & $\leq 1$ & $>8$ & 63.9 & 4.4 & 31.7 \\
\hline & Levofloxacin & 0.06 to $>4$ & $>4$ & $>4$ & 35.5 & 2.7 & 61.7 \\
\hline & Linezolid & 0.25 to $>8$ & 0.5 & 1 & 98.4 & & 1.6 \\
\hline & Oxacillin & 0.5 to $>2$ & $>2$ & $>2$ & 0.0 & & 100.0 \\
\hline & Teicoplanin & $\leq 0.5$ to 16 & 2 & 4 & 98.4 & 1.6 & 0.0 \\
\hline & Tetracycline & $\leq 0.5$ to $>8$ & $\leq 0.5$ & $>8$ & 81.4 & 0.5 & 18.0 \\
\hline & TMX-SMX & $\leq 0.5$ to $>4$ & 1 & $>4$ & 62.8 & & 37.2 \\
\hline & Vancomycin & $\leq 0.12$ to 2 & 1 & 2 & 100.0 & 0.0 & 0.0 \\
\hline \multirow[t]{8}{*}{ E. faecalis (438) } & Telavancin & $\leq 0.015$ to 0.5 & 0.12 & 0.12 & $90.1 / 99.8^{\mathrm{b}}$ & & \\
\hline & Ampicillin & $\leq 0.5$ to 2 & $\leq 0.5$ & 1 & 100.0 & & 0.0 \\
\hline & Daptomycin & $\leq 0.25$ to 4 & 0.5 & 1 & 100.0 & & \\
\hline & Levofloxacin & $\leq 0.5$ to $>4$ & 1 & $>4$ & 73.3 & 0.0 & 26.7 \\
\hline & Linezolid & $\leq 0.25$ to 4 & 1 & 1 & 99.8 & 0.2 & 0.0 \\
\hline & Tetracycline & $\leq 1$ to $>8$ & $>8$ & $>8$ & 24.4 & 1.6 & 74.0 \\
\hline & Teicoplanin & $\leq 2$ to $>16$ & $\leq 2$ & $\leq 2$ & 93.4 & 0.0 & 6.6 \\
\hline & Vancomycin & $\leq 0.5$ to $>16$ & 1 & 2 & 92.5 & 0.0 & 7.5 \\
\hline \multirow[t]{8}{*}{ E. faecium (346) } & Telavancin & $\leq 0.015$ to $>2$ & 2 & $>2$ & & & \\
\hline & Ampicillin & $\leq 0.5$ to $>8$ & $>8$ & $>8$ & 16.5 & & 83.5 \\
\hline & Daptomycin & $\leq 0.25$ to $>8$ & 1 & 2 & 99.4 & & \\
\hline & Levofloxacin & $\leq 0.5$ to $>4$ & $>4$ & $>4$ & 11.3 & 5.5 & 83.2 \\
\hline & Linezolid & $\leq 0.25$ to 8 & 1 & 2 & 99.4 & 0.0 & 0.6 \\
\hline & Tetracycline & $\leq 1$ to $>8$ & $>8$ & $>8$ & 24.9 & 4.6 & 70.5 \\
\hline & Teicoplanin & $\leq 2$ to $>16$ & $>16$ & $>16$ & 31.5 & 9.2 & 59.2 \\
\hline & Vancomycin & $\leq 0.5$ to $>16$ & $>16$ & $>16$ & 28.6 & 0.3 & 71.1 \\
\hline \multirow[t]{9}{*}{ S. pneumoniae (447) } & Telavancin & 0.004 to 0.03 & 0.008 & 0.015 & & & \\
\hline & Ceftaroline & $\leq 0.008$ to 0.5 & $\leq 0.008$ & 0.12 & 100.0 & & \\
\hline & Clindamycin & $\leq 0.12$ to $>1$ & $\leq 0.12$ & $>1$ & $85 . .5$ & 0.9 & 13.6 \\
\hline & Erythromycin & $\leq 0.015$ to $>2$ & 0.06 & $>2$ & 54.4 & 0.2 & 45.4 \\
\hline & Levofloxacin & 0.5 to $>4$ & 1 & 1 & 99.3 & 0.0 & 0.7 \\
\hline & Linezolid & 0.12 to 2 & 1 & 1 & 100.0 & & \\
\hline & Penicillin $^{\mathrm{c}}$ & $\leq 0.06$ to 4 & $\leq 0.06$ & 1 & 96.2 & 3.8 & 0.0 \\
\hline & Tetracycline & $\leq 0.012$ to $>4$ & 0.25 & $>4$ & 79.8 & 0.2 & 20.0 \\
\hline & Vancomycin & 0.06 to 0.5 & 0.25 & 0.25 & 100.0 & & \\
\hline \multirow[t]{11}{*}{ BHS $(1,083)$} & Telavancin & $\leq 0.002$ to 0.12 & 0.03 & 0.03 & 100.0 & & \\
\hline & Ceftaroline & $\leq 0.008$ to 0.03 & $\leq 0.008$ & 0.015 & 100.0 & & \\
\hline & Clindamycin & $\leq 0.015$ to $>2$ & 0.06 & $>2$ & 79.2 & 0.5 & 20.3 \\
\hline & Daptomycin & $\leq 0.06$ to 1 & 0.12 & $0 . \overline{5}$ & 100.0 & & \\
\hline & Erythromycin & $\leq 0.03$ to $>4$ & 0.06 & $>4$ & 62.1 & 0.8 & 37.0 \\
\hline & Levofloxacin & 0.06 to $>4$ & 0.5 & 1 & 99.5 & 0.3 & 0.2 \\
\hline & Linezolid & 0.5 to 1 & 1 & 1 & 100.0 & & \\
\hline & Penicillin & $\leq 0.03$ to 0.12 & $\leq 0.03$ & 0.06 & 100.0 & & \\
\hline & Tetracycline & $\leq 0.25$ to $>8$ & 0.5 & $>8$ & 51.2 & 2.0 & 46.7 \\
\hline & Teicoplanin & $\leq 0.06$ to 0.5 & 0.12 & 0.25 & $100.0^{\mathrm{d}}$ & & 0.0 \\
\hline & Vancomycin & $\leq 0.06$ to 1 & 0.25 & 0.5 & 100.0 & & \\
\hline \multirow[t]{11}{*}{ VGS (278) } & Telavancin & $\leq 0.002$ to 0.06 & 0.015 & 0.03 & 100.0 & & \\
\hline & Ceftaroline & $\leq 0.008$ to 0.5 & 0.015 & 0.06 & & & \\
\hline & Clindamycin & $\leq 0.015$ to $>2$ & 0.03 & $>2$ & 83.7 & 0.7 & 15.6 \\
\hline & Daptomycin & $\leq 0.06$ to 1 & 0.5 & 0.5 & 100.0 & & \\
\hline & Erythromycin & $\leq 0.03$ to $>4$ & 0.5 & $>4$ & 47.1 & 4.3 & 48.6 \\
\hline & Levofloxacin & $\leq 0.03$ to $>4$ & 1 & 2 & 92.4 & 0.7 & 6.9 \\
\hline & Linezolid & $\leq 0.06$ to 1 & 0.5 & 1 & 100.0 & & \\
\hline & Penicillin & $\leq 0.03$ to $>4$ & $\leq 0.03$ & 0.5 & 79.0 & 18.8 & 2.2 \\
\hline & Tetracycline & $\leq 0.25$ to $>8$ & 0.5 & $>8$ & 56.2 & 3.6 & 40.2 \\
\hline & Teicoplanin ${ }^{\mathrm{d}}$ & $\leq 0.06$ to 2 & 0.12 & 0.25 & 100.0 & & 0.0 \\
\hline & Vancomycin & $\leq 0.06$ to 1 & 0.5 & 0.5 & 100.0 & & \\
\hline
\end{tabular}

${ }^{\mathrm{a}}$ Criteria as published by CLSI (2016).

${ }^{\mathrm{b}}$ Or $99.8 \%$ against vancomycin-susceptible E. faecalis only $(N=405)$.

${ }^{c}$ Using parenteral nonmeningitis breakpoints.

${ }^{\mathrm{d}}$ Using EUCAST (2016) breakpoints.

I, intermediate; R, resistant; S, susceptible; TMX-SMX, trimethoprim-sulfamethoxazole. 
telavancin $\left(\mathrm{MIC}_{50 / 90}, 0.12 / 0.12 \mu \mathrm{g} / \mathrm{ml} ; 93.2 \%\right.$ susceptible of all isolates or $99.8 \%$ of vancomycin-susceptible $E$. faecalis), ampicillin (100.0\%), daptomycin (100.0\%), linezolid (99.8\%), teicoplanin (93.4\%), and vancomycin (92.5\%).

\section{Activity of telavancin against Enterococcus faecium}

Daptomycin and linezolid showed elevated susceptibility percentages (99.4\%) against Enterococcus faecium isolates and a total of $71.1 \%$ were vancomycin resistant with $96.0 \%$ displaying a VanA phenotype (Tables 1 and 3). Vancomycin resistance rates among E. faecium isolates varied by U.S. Census Bureau Division, ranging from $50.0 \%$ (West North Central) to $89.7 \%$ (East South Central) (Table 2).

Telavancin was most active against vancomycinsusceptible E. faecium $\left(\mathrm{MIC}_{50 / 90}, 0.03 / 0.06 \mu \mathrm{g} / \mathrm{ml}\right)$. Whereas telavancin was active against $\operatorname{VanB}$ isolates of E. faecium $\left(\mathrm{MIC}_{50 / 90}, 0.5 / 1 \mu \mathrm{g} / \mathrm{ml}\right)$, it was inactive against strains of both species with a VanA phenotype $\left(\mathrm{MIC}_{90},>2 \mu \mathrm{g} / \mathrm{ml}\right)$ (Table 1$)$.

\section{Activity of telavancin tested against S. pneumoniae}

Telavancin was active against $S$. pneumoniae $\left(\mathrm{MIC}_{50 / 90}\right.$, $0.008 / 0.015 \mu \mathrm{g} / \mathrm{ml})$ and all strains were inhibited at $\leq 0.03 \mu \mathrm{g} /$ $\mathrm{ml}$ (Table 1). Ceftaroline $\left(\mathrm{MIC}_{50 / 90}, \leq 0.008 / 0.12 \mu \mathrm{g} / \mathrm{ml}\right.$; $100.0 \%$ susceptible), levofloxacin ( $\mathrm{MIC}_{50 / 90}, 1 / 1 \mu \mathrm{g} / \mathrm{ml}$; 99.3\% susceptible), linezolid ( $\mathrm{MIC}_{50 / 90}, 1 / 1 \mu \mathrm{g} / \mathrm{ml} ; 100.0 \%$ susceptible), and vancomycin $\left(\mathrm{MIC}_{50 / 90}, 0.25 / 0.25 \mu \mathrm{g} / \mathrm{ml}\right.$; $100.0 \%$ susceptible) were highly active against U.S. strains of pneumococci (Table 3). Penicillin nonsusceptibility (MIC, $\geq 4 \mu \mathrm{g} / \mathrm{ml}$ ) occurred at a rate of $3.8 \%$ and erythromycin resistance (MIC, $\geq 1 \mu \mathrm{g} / \mathrm{ml}$ ) occurred at $45.6 \%$ (Table 3). Penicillin nonsusceptibility varied by U.S. Census Division, ranging from $17.6 \%$ (Pacific Division) to 53.5\% (West South Central) (data not shown).

\section{Activity of telavancin tested against BHS and VGS}

A total of 1,083 BHS were tested, $45.6 \%$ of which were Streptococcus agalactiae, $41.9 \%$ of which were Streptococcus pyogenes, and $12.5 \%$ of which were Streptococcus dysgalactiae (Table 1). Telavancin, ceftaroline, daptomycin, linezolid, penicillin, teicoplanin, and vancomycin inhibited all BHS tested at their respective breakpoints (Tables 1 and 3). Susceptibility to levofloxacin was $99.5 \%$ (Table 3 ). High rates of resistance occurred for clindamycin (constitutive resistance at $20.3 \%)$, erythromycin $(37.0 \%)$, and tetracycline (46.7\%) (Table 3). Macrolide resistance varied by division from a low of $22.0 \%$ (Pacific) to a high of $45.7 \%$ (East South Central) (data not shown).

The VGS were highly susceptible (100.0\%) to telavancin, daptomycin, linezolid, and vancomycin (Table 3). All strains of VGS were inhibited by $\leq 0.5 \mu \mathrm{g} / \mathrm{ml}$ of ceftaroline $\left(\mathrm{MIC}_{50 / 90}, 0.015 / 0.06 \mu \mathrm{g} / \mathrm{ml}\right.$ ) (Table 3). The susceptibility of the VGS was reduced to erythromycin (47.1\%), penicillin (79.0\%), and tetracycline (56.2\%) (Table 3). Susceptibility to clindamycin was $83.7 \%$ and levofloxacin resistance was $6.9 \%$ (Table 3). Telavancin MIC values among the VGS were predominantly from 0.008 to $0.03 \mu \mathrm{g} / \mathrm{ml}$ (modal MIC $0.015 \mu \mathrm{g} / \mathrm{ml}$ ) and no isolate exhibited a telavancin MIC value at the susceptible breakpoint of $\leq 0.12 \mu \mathrm{g} / \mathrm{ml}$ (Table 1).

\section{Discussion}

Telavancin susceptibility testing of $>8,000$ gram-positive pathogens demonstrated excellent activity and a sustained susceptibility percentage of $>99.9 \%$ overall against indicated species/groups (99.9\% during the period 2011-2012). Telavancin MIC population distributions were determined using the revised BMD method and have remained stable without evidence of MIC creep among all monitored species. ${ }^{6,9}$ Whereas the revised method demonstrates almost $100 \%$ coverage (susceptibility) of staphylococci, streptococci, and vancomycin-susceptible E. faecalis, telavancin is not active against the VanA phenotype of vancomycin-resistant enterococci (VRE) ( $\mathrm{MIC}_{90},>2 \mu \mathrm{g} / \mathrm{ml}$ ). These data confirm and extend the observations noted previously by Mendes et al. ${ }^{6}$ for U.S. isolates of gram-positive cocci when applying the appropriate BMD method and interpretive criteria.

Although resistance to other highly active anti-grampositive agents has emerged throughout the United States, it generally is low in most divisions of the country. ${ }^{6,12}$ In the present study, nonsusceptibility among target species (staphylococci, streptococci, and vancomycin-susceptible enterococci) to daptomycin, ceftaroline, and linezolid was virtually nil (range 0.0-0.9\%). Teicoplanin-intermediate and -resistant S. aureus and CoNS were not detected in 2015. Likewise, there were no vancomycin-intermediate or -resistant strains of S. aureus or CoNS detected in this sampling of U.S. sites. However, VRE and MRSA rates remain high and vary considerably across the United States. Overall rates of VRE and MRSA in 2015 (68.5\% and 44.9\%, respectively) were lower than those reported by Mendes et al. ${ }^{6}$ from 2011 to 2012 (73\% and $48 \%$, respectively), trends reported elsewhere. ${ }^{13,14}$

In conclusion, we have expanded on the previous results of Mendes et $a l^{6}{ }^{6}$ demonstrating sustained potency and spectrum of telavancin against contemporary gram-positive clinical isolates from across the United States. We have employed the modified BMD method along with revised clinical breakpoints to confirm an 8- to 32-fold greater potency of telavancin over daptomycin, linezolid, and vancomycin when tested against staphylococci and streptococci, irrespective of their resistance to other gram-positive agents. These results coupled with those of Mendes et al. ${ }^{6}$ should serve as the new benchmark for monitoring the in vitro activity of this lipoglycopeptide agent.

\section{Acknowledgments}

The authors wish to thank the following staff members at JMI Laboratories (North Liberty, IA): L. Duncan, L. Flanigan, M. Huband, M. Janechek, J. Oberholser, P. Rhomberg, J. Schuchert, J. Streit, and L. Woosley for technical support and/or assistance with manuscript preparation. The research and publication process was supported by Theravance Biopharma Antibiotics, Inc.

\section{Disclosure Statement}

This study was performed by JMI Laboratories and supported by Theravance Biopharma US, Inc., which included funding for services related to preparing this article. JMI Laboratories contracted to perform services in 2016 for Achaogen, Actelion, Allecra, Allergan, Ampliphi, API, Astellas, AstraZeneca, Basilea, Bayer, BD, Biomodels, Cardeas, 
CEM-102 Pharma, Cempra, Cidara, Cormedix, CSA Biotech, Cubist, Debiopharm, Dipexium, Duke, Durata, Entasis, Fortress, Fox Chase Chemical, GSK, Medpace, Melinta, Merck, Micurx, Motif, N8 Medical, Nabriva, Nexcida, Novartis, Paratek, Pfizer, Polyphor, Rempex, Scynexis, Shionogi, Spero Therapeutics, Symbal Therapeutics, Synolgoic, TGV Therapeutics, The Medicines Company, Theravance, ThermoFisher, Venatorx, Wockhardt, and Zavante. Some JMI employees are advisors/consultants for Allergan, Astellas, Cubist, Pfizer, Cempra, and Theravance. There are no speakers' bureaus or stock options to declare. JIS was an employee of Theravance Biopharma US, Inc., when this study was conducted and manuscript prepared.

\section{References}

1. Rubinstein, E., T. Lalani, G.R. Corey, Z.A. Kanafani, E.C. Nannini, M.G. Rocha, G. Rahav, M.S. Niederman, M.H. Kollef, A.F. Shorr, P.C. Lee, A.L. Lentnek, C.M. Luna, J.Y. Fagon, A. Torres, M.M. Kitt, F.C. Genter, S.L. Barriere, H.D. Friedland, and M.E. Stryjewski. 2011. Telavancin versus vancomycin for hospital-acquired pneumonia due to gram-positive pathogens. Clin. Infect. Dis. 52:31-40.

2. Rubinstein, E., M.E. Stryjewski, and S.L. Barriere. 2014. Clinical utility of telavancin for treatment of hospitalacquired pneumonia: focus on non-ventilator-associated pneumonia. Infect. Drug Resist. 7:129-135.

3. Stryjewski, M.E., D.R. Graham, S.E. Wilson, W. O'Riordan, D. Young, A. Lentnek, D.P. Ross, V.G. Fowler, A. Hopkins, H.D. Friedland, S.L. Barriere, M.M. Kitt, and G.R. Corey. 2008. Telavancin versus vancomycin for the treatment of complicated skin and skin-structure infections caused by gram-positive organisms. Clin. Infect. Dis. 46:1683-1693.

4. VIBATIV Package Insert 2016. Available at http://www .vibativ.com. Theravance Biopharma US, Inc (accessed 25 August 2016).

5. Draghi, D.C., B.M. Benton, K.M. Krause, C. Thornsberry, C. Pillar, and D.F. Sahm. 2008. Comparative surveillance study of telavancin activity against recently collected grampositive clinical isolates from across the United States. Antimicrob. Agents Chemother. 52:2383-2388.

6. Mendes, R.E., D.J. Farrell, H.S. Sader, R.K. Flamm, and R.N. Jones. 2015. Baseline activity of telavancin when tested against Gram-positive clinical isolates responsible for documented infections in USA hospitals (2011-2012) applying the revised susceptibility testing method. Antimicrob. Agents Chemother. 59:702-706.
7. Higgins, D.L., R. Chang, D.V. Debabov, J. Leung, T. Wu, K.M. Krause, E. Sandvik, J.M. Hubbard, K. Kaniga, D.E. Schmidt, Jr., Q. Gao, R.T. Cass, D.E. Karr, B.M. Benton, and P.P. Humphrey. 2005. Telavancin, a multifunctional lipoglycopeptide, disrupts both cell wall synthesis and cell membrane integrity in methicillin-resistant Staphylococcus aureus. Antimicrob. Agents Chemother. 49:1127-1134.

8. CLSI. 2016. M100-S26. Performance Standards for Antimicrobial Susceptibility Testing: 26th Informational Supplement. Clinical and Laboratory Standards Institute, Wayne, PA.

9. Farrell, D.J., R.E. Mendes, P.R. Rhomberg, and R.N. Jones. 2014. Revised reference broth microdilution method for testing telavancin: effect on MIC results and correlation with other testing methodologies. Antimicro. Agents Chemother. 58:5547-5551.

10. CLSI. 2015. M07-A10. Methods for Dilution Antimicrobial Susceptibility Tests for Bacteria that Grow Aerobically; Approved Standard-Tenth Edition. Clinical and Laboratory Standards Institute, Wayne, PA.

11. EUCAST. 2016. Breakpoint tables for interpretation of MICs and zone diameters. Version 6.0. Available at www .eucast.org/clinical_breakpoints/ (accessed 5 January 2016).

12. Flamm, R.K., R.E. Mendes, P.A. Hogan, J.M. Streit, J.E. Ross, and R.N. Jones. 2016. Linezolid surveillance results for the United States (LEADER Surveillance Program 2014). Antimicrob. Agents. Chemother. 60:2273-2280.

13. Jarvis, W.R., A.A. Jarvis, and R.Y. Chinn. 2012. National prevalence of methicillin-resistant Staphylococcus aureus in inpatients at United States health care facilities, 2010. Am. J. Infect. Control. 40:194-200.

14. Khatib, R., M. Sharma, S. Iyer, M.G. Fakih, K.M. Obeid, A. Venugopal, J. Fishbain, L.B. Johnson, M. Segireddy, J. Jose, and K. Riederer. 2013. Decreasing incidence of Staphylococcus aureus bacteremia over 9 years: greatest decline in community-associated methicillin-susceptible and hospital-acquired methicillin-resistant isolates. Am. J. Infect. Control. 41:210-213.

Address correspondence to: Rodrigo E. Mendes, PhD JMI Laboratories

345 Beave Kreek Centre, Suite A North Liberty, IA 52317

E-mail: rodrigo-mendes@jmilabs.com 